\title{
HUBUNGAN LAMA MENJALANI HEMODIALISA DAN ANEMIA DENGAN KUALITAS HIDUP PADA PASIEN GGK YANG MENJALANI HEMODIALISA DI UNIT HEMODIALISA RUMAH SAKIT TK. II 03.05.01 DUSTIRA
}

\author{
THE RELATION of LENGTH IN UNDERGOING THE HEMODIALYSIS AND \\ ANEMIA WITH QUALITY OF LIFE IN CRF PATIENT AT HEMODIALYSIS UNIT \\ DUSTIRA HOSPITAL TK. II 03.05.01
}

\author{
Dedi Supriadi $^{1}$, Evangeline Hutabarat ${ }^{2}$, Meliawaty Nur Airifin ${ }^{3}$ \\ Stikes Jendral A. Yani Cimahi \\ E-mail : evangelinehtbarat@gmail.com
}

\begin{abstract}
ABSTRAK
Pendahuluan: Gagal ginjal kronik (GGK) mengakibatkan penurunan fungsi ginjal yang irreversibel, yang memerlukan terapi berupa transplantasi ginjal atau hemodialisa. Tujuan utama hemodialisa yaitu mengendalikan uremia, kelebihan cairan dan ketidakseimbangan elektrolit. Ada banyak faktor yang dapat mempengaruhi kualitas hidup pasien GGK, diantaranya adalah lama menjalani hemodilaisa dan anemia. Tujuan: Penelitian ini bertujuan mencari hubungan antara lama menjalani HD dan anemia dengan kualitas hidup. Metode penelitian yang digunakan survey analitik dengan pendekatan cross sectional. Metode: Penelitian ini melibatkan semua pasien yang menjalani hemodialisa regular di Unit Hemodialisa Rumkit Tk. Il 03.05.01 Dustira Tahun 2018 yang memenuhi criteria inklusi yaitu 37 sample dengan teknik consecutive sampling. Pengumpulan data dilakukan secara langsung pada pasien dan didapatkan juga dari catatan rekam medic pasien. Analisa data menggunakan analisis univariat dan bivariat dengan uji chi square. Hasil: Sebanyak 21 orang (56.8\%) termasuk kategori lama menjalani HD (>24 bulan), sebagian besar dari responden sebanyak 20 orang $(54.1 \%)$ mengalami anemia ringan dan sebagian besar dari responden sebanyak 19 orang (51.4\%) memiliki kualitas hidup baik. Tidak terdapat hubungan antara lama menjalani HD dengan kualitas hidup pasien gagal ginjal kronik yang menjalani hemodialisa di Rumkit TK II 03.05.01 Dustira ( $p$ value $=0.634, \geq \alpha=0.05$ ) Diskusi: Tidak terdapat hubungan antara anemia dengan kualitas hidup pasien gagal ginjal kronik yang menjalanihemodialisa di Rumkit TK II 03.05.01 Dustira ( $p$ value = $0.879, \geq \alpha=0.05$ ). Bagi peneliti lain diharapkan dapat mengembangkan lagi penelitian lebih kompleks dengan melibatkan dan mencari faktor lain yang mempengaruhi kualitas hidup.
\end{abstract}

Kata kunci: Iama menjalani hemodialisa, anemia, kualitas hidup

\begin{abstract}
Introduction: Chronic renal failure (CRF) results in a decrease in irreversible kidney function, requiring therapy in the form of a kidney transplant or hemodialysis. The main purpose of hemodialysis is to control uremia, fluid overload and electrolyte imbalances. There are many factors that can affect the quality of life of patients with CRF, including long-term hemodialysis and anemia. Purpose: This study aims to find the relationship between long undergoing $H D$ and anemia with quality of life. Method: Research method used analytical survey with cross sectional approach This research involves all patients who undergo regular hemodialysis in Unit HemodialisaHospital TK. II 03.05.01 Dustira.The year 2018 that meets inclusion criteria is 37 samples with consecutive sampling technique. The data were collected directly on the patient and obtained from the patient's medic record. Data analysis used univariate and bivariate analysis with chi square test. Results: The results showed that as many as 21 people (56.8\%) had undergone HD (> 24 months), most of the respondent as many as 20 people (54.1\%) had mild anemia and most of the respondenr as many as 19 people
\end{abstract}

JURNAL

SKOLASTIK KEPERAWATAN

Vol, 4, No. 1

Januari - Juni 2018

ISSN: $2443-0935$

E-ISSN 2443 - 1699 
(51.4\%) had good quality of life. Disucssion: There was no correlation between long undergoing of $H D$ with quality of life of renal renal failure patients who undergoing hemodialysis in Hospital TK II 03.05.01 Dustira ( $p$ value $=0.634, \geq \alpha=0.05$ ) and there was no correlation between anemia with quality of life of renal renal failure patients undergoing hemodialysis in Hospital TK II 03.05.01 Dustira ( $p$ value $=0.879, \geq \alpha=$ 0.05). For futher researchers it is expected to develop more complex research by involving and looking for other factors that affect quality of life.

Key words: long undergoing hemodialysis, anemia, quality of life

\section{PENDAHULUAN}

Penyakit ginjal kronik (Chronic Kidney Disease/CKD) adalah gangguan fungsi ginjal yang progresif dan irreversible, dimana kemampuan tubuh gagal untuk mempertahankan metabolisme serta keseimbangan cairan dan elektrolit sehingga menyebabkan uremia (Smeltzer \& Bare, 2008). Penyakit gagal ginjal kronis (GGK) merupakan masalah kesehatan masyarakat global dengan prevalensi dan insidensi gagal ginjal yang meningkat, prognosis yang buruk dan biaya yang tinggi. Prevalensi GGK meningkat seiring meningkatnya jumlah penduduk usia lanjut dan kejadian penyakit diabetes melitus serta hipertensi.

Data statistik Perhimpunan Nefrologi Indonesia (PERNEFRI) menyebutkan bahwa jumlah pasien gagal ginjal total di Indonesia mencapai 70.000 orang dan hanya sekitar 13.000 orang yang melakukan cuci darah atau hemodialysis (Santoso, 2016). Jumlah pasien gagal ginjal kronik sebanyak 30.554di Jawa Barat, dan pasien yang menjalani hemodialisa rutin berjumlah 24.484 (Indonesian Renal Registry, 2015). Tahun 2016 di Kota Cimahi jumlah pasien dengan gangguan gagal ginjal akut berjumlah 1.292 dan penderita dengan gagal ginjal kronik sebanyak 2.008 (Dinkes Kota Cimahi, 2016).
Kualitas hidup pasien gagal ginjal sangat berkaitan dengan hemodialisa. Namun, hemodialisa bukan merupakan suatu terapi untuk menyembuhkan. Hemodialisa dilakukan hanya untuk mempertahankan kehidupan dan kesejahteraan pasien sampai fungsi ginjal pulih kembali. Hemodialisa merupakan terapi yang lama, mahal, serta membutuhkan restriksi cairan dan diet. Pasien akan kehilangan kebebasan karena berbagai aturan, pasien sangat tergantung pada pemberi layanan kesehatan. Tidak menutup kemungkinan pula pasien sering mengalami perpecahan di dalam keluarga dan di dalam kehidupan sosial. Pendapatan akan semakin berkurang atau bahkan hilang, akibat pasien tidak produktif. Berbagai faktor tersebut atau bahkan didukung beberapa aspek lain seperti aspek fisik, psikologis, sosioekonomi dan lingkungan dapat mempengaruhi kualitas hidup pasien gagal ginjal (Nurchayati, 2011).

Kualitas hidup yang optimal merupakan hal yang sangat penting diperhatikan dalam memberikan asuhan keperawatan secara komprehensif terhadap pasien hemodialisa. Menurut Molzhan (2006) dalam Young (2009), hal utama yang berhubungan dengan kualitas hidup pasien yang menjalani dialisis antara lain status fungsional dan kesehatannya, terapi yang dijalaninya, kemampuan bekerja, dukungan sosial, serta berbagai 
komorbiditas, gejala serta permasalahan yang terjadi selama terapi.

Menurut National Kidney Foundation, dalam menilai kualitas hidup pasien GGK yang menjalani hemodialisa faktor yang dinilai adalah akses vaskuler, dialysis adequacy, nutrisi, hipertensi, penyakit tulang (kontrol Phospat dan Calcium), serta anemia (NKF, 2002 dalam Clarkson \& Robinson, 2010). Anemia merupakan salah satu komplikasi pada GGK yang sering terjadi. Anemia terjadi pada 8090\% pasien GGK (Indonesian Renal Registry, 2015). Secara fungsional anemia didefinisikan sebagai penurunan jumlah masa eritrosit, sehingga tidak dapat memenuhi fungsinya untuk membawa oksigen dalam jumlah cukup ke jaringan perifer. Etiologi anemia pada keadaan GGK merupakan kelainan multifaktorial dan defisiensi erythropoietic stimulating factors (ESF). Pasien dengan anemia berat dan berlangsung lama memperlihatkan kelelahan mental dan fisik, penurunan kapasitas latihan, gangguan fungsi kognitif, penurunan libido dan fungsi seksual, dan nafsu makan hilang sehingga dapat mempengaruhi kualitas hidup pasien (Sukandar, 2013).

Anemia berperan dalam meningkatnya morbiditas dan mortalitas, rendahnya kualitas hidup pada pasien GGK serta mempercepat progres pasien menuju gagal ginjal terminal (Sukandar, 2013). Cindy, dkk (2015) melakukan penelitian pada pasien GGK yang menjalani hemodialysis dan ditemukan bahwa terdapat hubungan yang signifikan antara anemia dengan kualitas hidup pasien GGK yang sedang menjalani hemodialisa regular dan juga terdapat perbedaan derajat kualitas hidup antar derajat anemia.
Hasil analisis kuesioner KDQOL (Kidney Disease Quality of Life) menyebutkan bahwa rata-rata responden memiliki permasalahan berkaitan dengan keterbatasan untuk aktivitas berat, kurangnya pencapaian fisik, keterbatasan pekerjaan, pencapaian emosional yang kurang, anggapan akan gangguan penyakit ginjal, nyeri otot dan kram, gangguan dalam kemampuan bekerja, gangguan pembatasan cairan, kemampuan perjalanan, ketergantungan medis, dan gangguan kehidupan seksual.

Perawat hemodialisa memiliki peran penting dalam menurunkan angka morbility dan mortality pasien hemodialisa, yaitu berperan memberikan asuhan keperawatan kepadapasien dengan melaksanakan pengkajian berkelanjutan, memberikan pendidikan kesehatan, dukungan untuk kemampuan self care serta melakukan pemantauan secara menyeluruh. Perawat melaksanakan asuhan keperawatan secara komprehensif terhadap pasien hemodialisa diharapkan mengurangidan mencegah komplikasi selama menjalankan terapi sehingga dapat meningkatkan kualitas hidup pasienhemodialisa. (Kallenbach et al, 2009)

\section{BAHAN DAN METODE}

Jenis penelitian ini adalah kuantitatif dengan menggunakan metode survei analitik, yaitu suatu rancangan penelitian yang bertujuan untuk memperoleh penjelasan tentang faktor yang dapat mempengaruhi kualitas hidup. Secara umum studi analitik adalah suatu rancangan penelitian untuk melihat hubungan dua variabel atau lebih tanpa adanya perlakuan atau intervensi 
(Notoatmojo, 2010). Penelitian ini menggunakan pendekatan cross sectional. Rancangan penelitian cross sectional adalah suatu penelitian yang semua variabelnya, baik variabel independen maupun variabel dependen diobservasi atau dikumpulkan sekaligus dalam waktu yang sama (Notoatmodjo, 2010).

Populasi dalam penelitian ini adalah semua pasien yang menjalani hemodialisa secara reguler di Unit Hemodialisa Rumkit TK II 03.05.01 Dustira. Sampel pada penelitian ini diperoleh dengan menggunakan teknik consecutive sampling, yaitu subyek yang datang dan memenuhi kriteria pemilihan dimasukkan dalam penelitian sampai jumlah pasien yang diperlukan terpenuhi (Dahlan, 2010). Setelah pengumpulan data dilakukan selama 3 hari (2 shift dalam satu hari) didapatkan sebanyak 37 responden yang sesuai dengan besar sample yang telah ditentukan. Selama pengambilan data dilakukan, tidak ada responden yang drop out / menolak untuk menjadi reponden.

Alat yang digunakan untuk melakukan pengukuran kualitas hidupKuesioner KDQOL SF 1,3 merupakan kuesioner spesifik yang digunakan pada pasien dengan gangguan fungsi ginjal. KDQOL SF versi 1.3 mencakup 19 domain kualitas hidup pasien penyakit ginjal kronik yang menjalani hemodialisa, 19 domain tersebut adalah: Gejala/masalah yang menyertai, efek penyakit ginjal, beban akibat penyakit ginjal, status pekerjaan, fungsi kognitif, kualitas interaksi sosial, fungsi seksual, tidur, dukungan yang diperoleh, dorongan dari staf dialisis, kepuasan pasien, fungsi fisik, keterbatasan akibat masalah fisik, rasa nyeri yang dirasakan, persepsi kondisi kesehatan secara umum kesejahteraan emosional.
Sedangkan data lamanya menajalani hemodialisa serta data anemia pasien peneliti mengambil dari rekam medic responden. Data dianalisis secara univariat dan bivariat. Untuk univariat mengguankan nilai frekuensi serta presentasi sedangkan biavariat menggunakan uji chi square.

\section{HASIL}

\section{Analisa Unviariat}

Distiribusi frekuensi lamanya menjadi pasien HD pada responden penelitian dapat dilihat pada table 1 berikut ini.

Tabel 1. Distribusi frekuensi lama menjalani HD pada pasien GGK yang menjalani HD di Unit Hemodialisa Rumkit TK. II 03.05.01 Dustira Maret 2018

\begin{tabular}{ccc}
\hline Lama HD & Jumlah & Persentase (\%) \\
\hline Baru ( $\leq 24$ bulan) & 16 & 43,2 \\
$\begin{array}{c}\text { Lama (> 24 } \\
\text { bulan) }\end{array}$ & 21 & 56,8 \\
Total & 37 & 100 \\
\hline
\end{tabular}

Distiribusi frekuensi kejadian anemia pada pasien HD yang menjadi responden penelitian dapat dilihat pada table 2 berikut ini. 
Tabel 2. Gambaran anemia pada pasien GGK yang menjalani HD di Unit Hemodialisa Rumkit TK. II 03.05.01 Dustira bulan Maret 2018.

\begin{tabular}{|c|c|c|}
\hline Anemia & Jumlah & Persentase (\%) \\
\hline $\begin{array}{c}\text { Ringan } \\
\text { (Hb 8,D-I0,0 } \\
\text { gr/dl) }\end{array}$ & 20 & 54,1 \\
\hline $\begin{array}{c}\text { Sedang } \\
\text { (6,0-7,9 gr/dl) }\end{array}$ & 14 & 37,8 \\
\hline $\begin{array}{c}\text { Berat } \\
\left(H_{b}<6 \mathrm{gr} / \mathrm{dl}\right)\end{array}$ & 3 & 8,1 \\
\hline Total & 37 & 100 \\
\hline
\end{tabular}

Distiribusi frekuensi kualitas hidup pasien GGK yang menjalani HD dapat dilihat pada table 3 berikut ini.

Tabel 3. Distribusi frekuensi kualitas hidup pada pasien GGK yang menjalani HD di Unit HemodialisaRumkit TK. II 03.05.01 Dustira bulan Maret 2018.

\begin{tabular}{ccc}
\hline Kualitas Hidup & Jumlah & Persentase (\%) \\
\hline Baik & 19 & 51,4 \\
Buruk & 18 & 48,6 \\
Total & 37 & 100 \\
\hline
\end{tabular}

\section{Analisis Bivariat}

a. Hubungan Lama Menjalani HD dengan Kualitas Hidup
Tabel 4. Distribusi lama menjalani HD dengan kualitas hidup pasien GGK yang menjalani hemodialisa di Unit Hemodialisa Rumkit TK. II 03.05.01 Dustira bulan Maret 2018.

\begin{tabular}{|c|c|c|c|c|c|}
\hline \multirow{3}{*}{$\begin{array}{l}\text { Lama } \\
\text { HD }\end{array}$} & \multicolumn{3}{|c|}{ Kualitas Hidup } & \multirow[t]{2}{*}{ Total } & \multirow{2}{*}{$\begin{array}{l}P \\
\text { value }\end{array}$} \\
\hline & \multicolumn{2}{|c|}{ Baik } & Baik & & \\
\hline & $\mathrm{N}$ & $\%$ & $\%$ & $\%$ & 0,634 \\
\hline $\begin{array}{l}\text { Ваги } \\
\text { ( } \leq 24 \\
\text { bulan) }\end{array}$ & 7 & 43,75 & 56,25 & 100 & \\
\hline $\begin{array}{l}\text { Lama } \\
\text { (> 24 } \\
\text { bulan) }\end{array}$ & 12 & 57,14 & $9 \quad 42,86$ & 100 & \\
\hline Total & 19 & & 18 & 37 & \\
\hline
\end{tabular}

Berdasarkan hasil uji chi-square diperoleh $\mathrm{p}$ value $=0,634 \geq \alpha=0,05$ menunjukkan tidak ada hubungan antara lama menjalani HD dengan kualitas hidup pada pasien GGK yang menjalani HD.

b. Hubungan Anemia dengan Kualitas Hidup

Tabel 5. Distribusi anemia dengan kualitas hidup pasien GGK yang menjalani hemodialisa di Unit Hemodialisa Rumkit TK. II 03.05.01 Dustira bulan Maret 2018.

\begin{tabular}{|c|c|c|c|c|c|c|c|}
\hline \multirow[t]{3}{*}{ Anemia } & \multicolumn{4}{|c|}{ Kualitas Hidup } & \multirow{2}{*}{\multicolumn{2}{|c|}{ Total }} & \multirow{2}{*}{$\begin{array}{l}P \\
\text { value }\end{array}$} \\
\hline & \multicolumn{2}{|c|}{ Baik } & \multicolumn{2}{|c|}{ Baik } & & & \\
\hline & $\mathrm{N}$ & $\%$ & $\mathrm{~N}$ & $\%$ & $\mathrm{~N}$ & $\%$ & 0,879 \\
\hline Ringan & $\|$ & 55,0 & g & 45,0 & 20 & 100 & \\
\hline $\begin{array}{l}\text { Sedang } \\
+ \text { Berat }\end{array}$ & 8 & 47,1 & 乌 & 52,9 & 17 & 100 & \\
\hline Total & 19 & & 18 & & 37 & 100 & \\
\hline
\end{tabular}

Berdasarkan hasil uji chi-square diperoleh $\mathrm{p}$ value $=0,879 \geq \alpha=0,05$ menunjukkan tidak ada hubungan antara anemia dengan kualitas hidup pada pasien GGK yang menjalani HD. 


\section{PEMBAHASAN}

Hasil penelitian ini diperoleh $\mathrm{p}$ value $=$ $0,634 \geq \alpha=0,05$, menunjukkan tidak ada hubungan antara lama menjalani HD dengan kualitas hidup pada pasien GGK yang menjalani HD. Hasil penelitian ini sesuai dengan penelitian Rahman, et all (2016) yang melakukan penelitian tentang hubungan lama menjalani HD dengan kualitas hidup pada pasien GGK yang menjalani hemodialisa di RSUP Kandou Manado didapatkan nilai $p=0,579 \geq \alpha=$ 0,05 yang berarti tidak terdapat hubungan antara lama menjalani hemodialisa dengan kualitas hidup pada pasien GGK yang menjalani hemodialisa.

Hal ini juga sesuai dengan hasil penelitian yang dilakukan oleh Dewi, et all (2015) tentang hubungan lama menjalani hemodialisa dengan kualitas hidup pasien yang menjalani hemodialisa di Unit hemodialisa Rumah Sakit Umum PKU Muhammadiyah Yogyakarta sebanyak 60 sampel, didapatkan hasil nilai $\mathrm{p}$ value $=$ $0,739 \geq \alpha=0,05$ yang berarti tidak terdapat hubungan antara lama menjalani hemodialisa dengan kualitas hidup pada pasien GGK yang menjalani hemodialisa.

Hasil penelitian ini berbanding terbalik dengan hasil penelitian yang dilakukan Nurchayati (2010) di RSI Fatimah Cilacap dan RSUD Banyumas yang meneliti tentang faktor-faktor yang mempengaruhi kualitas hidup pasien GGK yang menjalani hemodialisa, didapatkan adanya hubungan antara lama waktu menjalani HD dengan kualitas hidup ( $\mathrm{p}$ value $=0.035$ ) dan $\mathrm{OR}=2.637$, yang artinya responden yang belum lama menjalani HD beresiko 2,6 kali hidupnya kurang berkualitas dibandingkan yang sudah lama menjalani HD.
Penelitian Yuliaw (2009) menemukan bahwa faktor demografi yang mempengaruhi kualitas hidup pasien gagal ginjal kronik yang menjalani hemodialisa adalah umur, jenis kelamin, pendidikan, pekerjaan dan lama menjalani $\mathrm{HD}$, sehingga selain faktor lamanya menjalani $\mathrm{HD}$, faktor yang lain juga mungkin berpengaruh terhadap kualitas hidup pasien.

Berdasarkan hasil analisis kuisioner KDQOL SF 1.3 menyebutkan bahwa ratarata responden memiliki status kesehatan secara umum cukup, permasalahan berkaitan dengan keterbatasan untuk aktivitas berat, kurangnya pencapaian fisik, keterbatasan pekerjaan, pencapaian emosional yang kurang, anggapan akan gangguan penyakit ginjal, nyeri otot dan kram, gangguan dalam kemampuan bekerja, gangguan pembatasan cairan, kemampuan perjalanan, dan ketergantungan medis.

Sesuai dengan teori berduka menurut Yosep (2010), berduka adalah respon emosi yang diekspresikan terhadap kehilangan yang dimanifestasikan adanya perasaan sedih, cemas, gelisah, sesak nafas, susah tidur dan lain-lain. Berduka merupakan respon normal yang terjadi ketika seseorang mengalami kehilangan. Kehilangan dapat terjadi karena kehilangan orang yang dicintai, kehilangan fungsi organ pada tubuh, kehilangan susasana lingkungan yang sangat dikenal, kehiangan objek eksternal dan kehilangan seseorang yang meninggal. Fase berduka terdiri dari fase pengingkaran, fase marah, fase tawar menawar, fase depresi dan fase menerima. Berdasarkan hasil penelitian bahwa terdapat sebagian besar dari responden 
$(57,14 \%)$ telah lama menjalani HD (> 24 bulan) dengan kualitas hidupnya baik sehingga pasien tersebut bisa dikatakan telah berada pada fase menerima.

Dapat disimpulkan dari penelitian ini bahwa semakin lama pasien menjalani HD maka pasien semakin patuh untuk menjalani HD karena biasanya responden telah mencapai tahap menerima ditambah mereka juga kemungkinan banyak mendapatkan pendidikan kesehatan dari perawat dan juga dokter tentang penyakit dan pentingnya melaksanakan HD secara teratur bagi mereka. Dalam pengobatan yang memerlukan jangka panjang akan memberikan pengaruh-pengaruh bagi penderita seperti tekanan psikologi bagi penderita tanpa keluhan atau gejala penyakit saat dinyatakan sakit dan harus menjalani pengobatan yang lama, tetapi responden yang telah lama menjalani terapi hemodialisa cenderung memiliki tingkat cemas lebih rendah dibandingkan dengan responden yang baru menjalani hemodialisa, hal ini disebabkan karena dengan lamanya seseorang menjalani hemodialisa, maka seseorang akan lebih adaptif dengan tindakan dialisis. Pasien yang sudah lama menjalani terapi hemodialisa kemungkinan sudah dalam fase penerimaan.

Dari segi spiritual juga, hampir seluruh dari responden mengatakan bahwa walaupun saya diberikan penyakit ini saya masih tetap bersyukur dan berusaha menjalaninya dengan ikhlas. Dengan dorongan yang kuat dari keluarga dan orang-orang terdekat membuat responden menjadi semangat dalam menjalani hemodialisa walaupun terapi ini harus dijalani seumur hidupnya.
Hasil penelitian ini menghasilkan $\mathrm{p}$ value $=0,879 \geq \alpha=0,05$ menunjukkan tidak ada hubungan antara anemia dengan kualitas hidup pada pasien GGK yang menjalani HD. Ini berbanding terbalik dengan hasil penelitian yang dilakukan oleh Cindy, et al tahun 2016 terhadap pasien yang menjalani hemodialisa di Instalasi Tindakan Khusus (ITK) Hemodialisa RSUP Prof. dr. R.D. Kandou Manado sebanyak 60 sampel, dengan nilai $\mathrm{p}$ value $=0,000 \leq \alpha=0,05$ yang berarti terdapat hubungan antara anemia dengan kualitas hidup pada pasien GGK yang menjalani hemodialisa.

Hasil penelitian ini juga berbanding terbalik dengan penelitian yang dilakukan oleh Nurchayati (2010). Pada penelitian tersebutjumlah responden yang menderita anemia dan hidupnya kurang berkualitas adalah sebagian besar dari responden yaitu sebanyak 34 orang $(58.6 \%)$, responden yang tidak anemia dengan kualitas hidup kurang baik sebagian kecil dari responden yaitu sebanyak 11 orang (29.7\%). Hasil uji statistik diperoleh $\mathrm{p}$ value $=0.011$ maka disimpulkan ada hubungan antara kadar $\mathrm{Hb}$ dengan kualitas hidup pada responden di RSI Fatimah Cilacap dan RSUD Banyumas. Dari hasil analisis diperoleh pula bahwa $\mathrm{OR}=3.348$, artinya responden dengan anemia memilikipeluang $3.3 \mathrm{kali}$ kualitas hidupnya kurang baik dibanding yang tidak anemia.

Hasil penelitian diperoleh bahwa diantara pasien GGK yang menjalani hemodialisa terdapat hampir setengah dari responden yaitu 9 orang $(45,0 \%)$ yang mengalami anemia ringan memiliki kualitas hidup buruk, sedangkan hampir setengah dari responden yaitu 9 orang $(52,9 \%)$ mengalami anemia sedang dan berat memiliki kualitas hidup buruk. 
Sampel dalam penelitian ini sebagian besar dari responden yaitu 11 orang $(55,0 \%)$ mengalami anemia ringan dengan kualitas hidupnya baik dan hampir setengah dari responden yaitu 8 orang $(47,1 \%)$ mengalami anemia sedang+berat dengan kualitas hidupnya baik. Akibat anemia ringan berdasarkan wawancara dengan pasien, pasien masih merasakan nafsu makan karena keluhan mual dan muntah tidak terlalu dirasakan oleh pasien, sehingga asupan asam folat dan zat besi dari intake makanan masih bisa masuk ke dalam tubuh sehingga pasien masih mampu untuk melakukan aktivitas sehariharinya walaupun ada sedikit keterbatasan sehingga hal ini mampu untuk meningkatkan kualitas hidup pasien.

Anemia dapat terjadi pada hampir semua pasien GGK, menyebabkan kematian dini serta mengurangi kualitas hidup karena menyebabkan kelelahan, penurunan kemampuan kapasitas latihan, penurunan kemampuan kognitif serta gangguan imunitas. Target $\mathrm{Hb}$ yang tinggi direkomendasikan karena dari berbagai studi observasi ditemukan bahwa kadar $\mathrm{Hb}$ yang tinggi dapat meningkatkan ketahanan pasien dan meningkatkan kualitashidup.

Pasien dengan penyakit ginjal kronis, anemia terutama berkembang dari gangguan sintesis di ginjal akibat penurunan eritropoetin. Kekurangan zat besi juga umum pada pasien dengan penyakit ginjal kronis. Kekurangan zat besi dapat tetap, sering karena asupan diet yang buruk atau kadang-kadang tersembunyi pendarahan, atau fungsional, ketika ada ketidakseimbangan antara kebutuhan besi dari sumsum erythroid dan pasokan zat besi. Kekurangan zat besi menyebabkan penurunan pembentukan hemoglobin sel darah merah, menyebabkan anemia mikrositik hipokrom. Penyebab lainnya untuk anemia pada penyakit ginjal kronis termasuk adanya inhibitor uremik (misalnya hormon paratiroid, sitokin inflamasi), hidup dengan pengurangan setengah dari sirkulasi sel darah, dan kekurangan folat atau vitaminB12.

Adapun dampak anemia terhadap fungsi fisik pada pasien dialisis dengan anemia memiliki nilai Volume $\mathrm{O}_{2} \max 50 \%$ dibandingkan dengan orang sehat ataupun yang seusia. Karena level oksigen yang rendah maka menyebabkan pasien kesulitan untuk melaksanakan aktivitas harian atau bekerja sesuai dengan normal. Pasien dengan level $\mathrm{Hb}$ yang rendah berefek negatif terhadap kualitashidupnya. Pasien dengan levelHb <11 g/dL mengalami penurunan fungsi fisik yang menyebabkan keterbatasan dalam melakukan rutinitas harian. (Gregory, 2005) dalam Nurchayati (2010)

Pada pasien dengan dialisis mengalami penurunan fungsi kognitif yang dimanifestasikan dengan kebingungan, gangguan memori, tidak mampu berkonsentrasi, dan penurunan kesadaran mental. Percobaan klinis telah menemukan adanya efek anemia terhadap kesehatan psikologis dan sosial pada pasien hemodialisa, dengan meningkatkan level $\mathrm{Hb}$ dapat meningkatkan kesehatan psikologis dan sosial pada pasien hemodialisa yang mengalami anemia.

Penatalaksanaan anemia pada pasien GGK harus bersifat terpadu. Penatalaksanaan secara tepat akan memberikan respon yang adekuat dan secara nyata akan meningkatkan kualitas hidup pasien. Saat ini terapi EPO masih 
menjadi pilihan utama terapi anemia pada pasien GGK. Agar pemberian terapi EPO dapat memberikan hasil yang optimal, seorang dokter hendaknya memperhatikan berbagai aspek dan mencari faktor utama penyebab anemia. Terapi tambahan lain seperti injeksi iron sucrose, injeksi vitamin $\mathrm{C}$, dan suplementasi asam folat juga dapat diberikan sebagai penunjang. Selain itu, Terapi yang adekuat dapat mempertahankan target $\mathrm{Hb}$

Pemeriksaan $\mathrm{Hb}$ di tempat penelitian ini dilakukan rutin setiap sebulan sekali. Jika pasien mengalami anemia, lalu diberikan tranfusi pada HD periode berikutnya dan setelah selesai tranfusi kemudian pasien diperiksa kembali kadar $\mathrm{Hb}$ post tranfusi. Selama ini protap pemberian tranfusi darah dijalankan, karena untuk pemberian eritropoetin dan pemeriksaan Ca Phospat harganya sangat mahal sehingga pasien tidak mampu untuk membiayai (sebagian besar pasien tanggungan BPJS dan jika mendapat eritropoetin harus membayar sendiri).

\section{KESIMPULAN}

Tidak terdapat hubungan yang signifikan antara lama menjalani HD dan anemia dengan kualitas hidup pada pasien GGK yang menjalani HD di Unit Hemodialisa Rumkit TK. II 03.05.01 Dustira dengan $\mathrm{p}$ value $=0,634$ ( $\mathrm{p}$ value $\geq \alpha$

\section{DAFTAR PUSTAKA}

Arikunto, Suharsimi. (2013). Manajemen Penelitian. Jakarta: PT RinekaCipta

Black, J.M, \& Hawks, J.H. (2009). Medical Surgical Nursing; $8^{\text {th }}$ edition. Canada: Elsevier

Cindy, dkk. (2016). Hubungan Anemia Dengan Kualitas Hidup Pasien Penyakit Ginjal Kronik Yang Sedang Menjalani Hemodialisis Regular, Jurnal e-Clinic (eCl), 4 (1), 106-107

Clarkson, K.A, Robinson, K. (2010). Life on Dialysis; A Lived Experiences. Nephrology Nursing Journal, 37(1),29-35

Dewi, Sufiana Puspita. (2015). Hubungan lamanya hemodialisa dengan Kualitas hidup pasien gagal ginjal Di RS PKU Muhammadiyah Yogyakarta, Tesis, Jakarta, Indonesia

DinasKesehatan Kota Cimahi. (2016). Data Penderita Gagal Ginjal di Kota Cimahi.

Fructuoso MR, Castro R, Prata C, \& Morgado T. (2011). Quality of life in chronic kidney disease. RevistaNefrologia, 1(31), 91-6.

Harmaini F. (2008). Uji Keandalan dan Kesahihan Formulir European Quality of Life - 5 Dimensions (EQ-5D) untuk Mengukur Kualitas Hidup Terkait Kesehatan pada 
Usia Lanjut di RSUPNCM, Tesis, Jakarta, Universitas Indonesia.

Hays R, Kallich J, Mapes D, Coons S. Kidney disease quality of life short form (KDQOL-SF), version 1.3: A manual for use and scoring. 1995; $P \quad$ - 7994. Avalable at: http://www.rand.org/content/dam/ rand/pubs/papers/2006/P7994.pdf. Diperolehtanggal12 Januari 2018.

Indonesian Renal Registry (2015). Indonesian Renal Registry 2015. Available at:https://www.indonesianrenalreg istry.org Diperoleh tanggal 7 Januari 2018

Info Datin. (2017). Prevalensi Penyakit Gagal Ginjal Kronik. Available $a t:$ http://www.depkes.go.id/downl oad.php?file $=$ download/pusdatin $/ \mathbf{i}$ nfodatin/infodatin\%20ginjal\%202 017.pdf. Diperoleh tanggal 6 Januari 2018.

Kallenbach, J.Z., Gutch, C.F., Stoner, M.H, Corea, A.L. (2009). Review of Hemodialysis for Nurses and Dialysis Personal (Ed.7). St. Louis: Elsevier Mosby.

Levin et al. (2008). Guidelines for the management chronic kidney disease. Available $a t:$ http://www.cmaj.ca/. Diperolehtanggal17 Januari 2018.

Widyastuti, R. (2014). Korelasi Lama Menjalani Hemodialisis dengan Indeks Massa Tubuh Pasien Gagal Ginjal Kronik di RSUD Arifin
Achmad provinsi Riau. Jurnal Gizi, 1 (2), 1- 